\title{
Can Bioethics Protect the Holders of Compromised Decisional Competence?
}

\author{
Vania Novelli Domingues ${ }^{1,2}$ \\ Monica Domingues Monteiro ${ }^{3}$, \\ Jose Antonio Cordero da Silva ${ }^{1,2}$, Guilhermina Rego ${ }^{1}$
}

1 Faculdade de Medicina, Universidade do Porto, Portugal.

2 Conselho Federal de Medicina, Brasilia, DF, Brasil.

3 Universidade Estadual do Rio de Janeiro, Rio de Janeiro, RJ, Brasil.

Contact information:

Vania Novelli Domingues.

Address: SGAS 915 Lote 72.

Zip code: 70390-150. Brasilia, DF Brazil. Tel: 6134455900.

झ doutoradobioetica@portalmedico.org.br vanianovelli@globo.com

Keywords

Bioethics; Advance Directives of Will; Incompetent.

\section{Introduction}

Society has been accompanying a profound change in medicine, which, with technological advances that are increasingly effective, keep patients with chronic diseases with an increasingly long life, not 
always linked to a good quality of life, with comfort and preservation of autonomy. Associated with this condition, it is notorious that there is a paternalistic functioning of Medicine in some aspects, which in the Code of Medical Ethics [1], in article 32, it says "It is forbidden for the physician to cease using all available diagnostic and treatment methods, scientifically recognized and within their reach, in favor of the patient." The article, when interpreted, disconnected from the others, keeps the doctor as the sole holder of the ability to decide, when choosing a treatment for any patient.

It is crucial to note that, although resource advances may affect the physician, giving him the sense of increased power and control over death, that not always corresponds to the desire of the patient. In other articles, namely article 34, "It is forbidden for the physician to fail to inform the patient about the diagnosis, the prognosis, the risks and the objectives of the treatment, except when direct communication can cause them harm, and in that case, it is recommended to communicate with the legal representative of the patient", article 39, "It is forbidden for the physician to oppose to a medical committee or a second opinion requested by the patient or their legal representative" and article 41, "It is forbidden for the physician to shorten the life of a patient even if that is a request made by either the patient or their legal representative" but in its single paragraph, it emphasizes the value of palliative care in the case of incurable, terminal illnesses, seeking to provide comfort to the patient, avoiding therapeutic or diagnostic actions that are either useless or obstinate, taking into account the wishes of the patient or their legal representative.

In the last three articles of the Code of Medical Ethics [1] already quoted, there is a growing appreciation of the patient's autonomy, in accordance with the development of an increasingly ethical and plural society.

The patient's competence to decide is essential for the full exercise of autonomy and it is listed in the structural elements of informed consent, according to Tom Beauchamp and James Childress [2].

If the person possesses the competence to understand what is being communicated and the ability to decide, while acting voluntarily, the subject of appreciation and respect for the patient's desire is met. The area with the largest gap is in the protection of the population that can't fulfill the necessary prerequisites for the elaboration of valid and informed consent within the parameters of Bioethics.

\section{Method}

This is a narrative review on compromised decisional competence. This research deals with the analysis of bibliographic references of articles in the five years of publication through the keywords: living will and incompetent.

From March 11 to March 17, 2018, two articles were returned to the Pubmed database and none to Scielo, Cochrane Library and Digital Library USP, within five years of publication.

Resolutions and opinions related to the topic were also analyzed, in the Code of Medical Ethics of the Federal Medical Council [1].

\section{Results}

According to Bravo G, Rodrigues C, Theriaul V, Arcaud M, Downie J, Dubois M et al (2017), in the first article that returned in the research, the concern would be answering if medical assistance in death should be extended to incompetent patients with dementia [3].

The article references to the fact that Alzheimer's disease is increasing throughout the world. Dementia is reported to affect more than 37 million people worldwide, with a forecast of growing to more than 115 million by 2050 .

In the early stages, quality of life can be quite reasonable, however, according to the article quoted, the fear of living through the more advanced stages 
of the disease is triggering requests for medical assistance in the death process.

Legislation in Canada, specifically in the province of Quebec, has been modified and allows patients with eligibility criteria, including decision-making competence, to have access to this type of assistance in the process of death.

There are arguments when it comes to extending this procedure of assistance in the process of death to incompetent patients, as long as there are adequate safeguards, and in that same article it is questioned whether or not those safeguards could protect the individuals vulnerable to abuse and coercions. Very sensitive issues which are difficult to control.

The article also presents favorable and unfavorable arguments for euthanasia and assisted suicide, putting forward reflections on the agenda. It also presents a questionnaire developed on the issue of assistance in the death process, in order to be directed to groups that are some way involved in the theme and considers that self-administration of the questionnaire used, even in patients in the early stages o dementia, would not be adequate and the existence of an interviewer who could understand any negative reaction of the interviewee with Alzheimer's dementia would be important, because it would allow the interviewer to take the appropriate measures in the event of an unfavorable reaction.

In the second article, Chan TK, Tipoe GL (2013), addresses the problem of children potentially donating stem cells to their siblings. [4]

The emotional condition of parents and children was analyzed in the article, pointing to a possible compromise in their condition of impartiality, being often forgotten that the child, a potential donor, would be exposed, for example, to injuries in bone marrow transplantation and peripheral blood, which is the clinical situation mentioned in the article.

It was considered as not being legally or morally acceptable the violation of the right of minors, seen as donors, not being taken into account the right to their own physical and emotional integrity.

In the text, it was suggested that "policy be modified to fully meet the legal requirements for implementation in the United Kingdom [4].

Regarding the research done in the Resolutions and Decisions of the Federal Medical Council of Brazil, FCM Resolution No. 1,995/2012 [5] and FCM Order No. 526/2016 [6], all related to the issue of the Advance Directives of Will and its regulation.

\section{Discussion}

According to the results presented in this review, in the perspective of Bioethics, the small number of studies, researches and assignments related to this issue is concerning, which can indicate that the small number of articles published in these databases, may create the necessity of further bibliographical surveys and studies, with the goal of further researches related to patients with reduced competence to decide about their life and the treatments to which they would be submitted to, or even incompetent, seen in a condition of greater vulnerability due to the characteristics of their mental health.

The basic principles of protection of the human being, whether competent or incompetent, are already well founded, initially in the World Medical Association, Helsinki Declaration [7], and in the Convention for the Protection of Human Rights and Dignity of the human being in the face of applications in Biology and Medicine [8] and in the Convention about Bioethics and Human Rights [9]. It occurs that, in their applicability, these basic principals undergo numerous pressures, depending on the prevalent interests in the society in which they occur.

In the case of dementia holders [3], the presumed use of resources of the health system for an indefinite time, demanding more care support, makes these patients potential victims of abuse and pressure to join the group of those who think of 
euthanasia or assisted suicide as a solution for their conflicts.

In Brazil, practices such as euthanasia and assisted suicide are not allowed, according to the Medical Code of Ethics [1], in its article 41, but we have a lot to reflect on when it comes to the FCM Resolution no. 1.995 / 2012 [5] and its applicability. This resolution "establishes the criteria for anyone - as long as they are of legal age and fully aware - to define with their physician the therapeutic limits at the terminal stage," with this procedure having the formal name of Advance Directives of Will.

The Advance Directives of Will (ADW) seek to value the autonomy of the patient as long as that is what the patient desires, but there is a lot to discuss, in order to find a model of the ADW adapted to national reality [10], which can translate into numerous difficulties inherent in the lack of knowledge of ADW, the lack of specific legislation, legal uncertainty and other conditions to be discovered.

In the model proposed for ADW, there is the inclusion of living will, which is a type of document in which the holders of the disease defines beforehand which medical procedures they would accept to be submitted to, foreseeing the possibility of being unable to adequately express itself on this issue, in addition to the appointment of a health care proxy, who would be a person trusted by the patient, because in situations not foreseen in the Vital Testament (VT), the health care proxy could speak for the patient, about new situations not foreseen in the course of the illness.

Much has been criticized in the term Vital Testament, since this term defines something that distances itself from the traditional concepts of a testament [11] and the right of successions. Moreover, its effect is not posterior to death, but rather anterior [11], with bioethics being linked to what is one of its pillars, respect for the autonomy and dignity of the patient, regarding the acceptance of future treatments, which the patient will or will not be submitted to, as defined on theirVT.
As for the regulation of the ADW, there has already been a draft law number 524/2009, which proposed these regulations but was closed [12]. It is questioned whether the regulation itself would improve the doctor's and the population's knowledge about ADWs. A step-by-step approach is being built, as part of the recognition of patients' autonomy and determination, which is one of the marks of the end of the 20th century [13].

Another important aspect is found in the moral and ethical difficulties to understand the experience of the demented individual, who in their advanced stage should be regarded as having terminal illness [14], aiming a quality of life, dignity and comfort and not the maintenance of life at any price, always being aware that there may be interests other than the patient's well-being, such as the possibility of running into managers' interests in reducing expenses [15], since these are patients who often demand long and complex treatments.

Other factors need to be addressed for low adherence to ADW. It was observed that even after explaining their applicability and importance, there was low adherence, and the lack of knowledge about the topic is significant even among physicians and medical students [16]. With this situation, the dissemination of the ADW becomes more difficult and, culturally, there is no habit of talking about finitude.

The question of finitude becomes a distant subject, moved to the hospital, away from the social sphere, also stimulated by technology, which gives the sensation of omnipotence and control, and may lead to the use of futile treatments (not aimed at the patient's well-being) and disproportionate (dysthanasia), in addition to turning ADWs into a distant and unnecessary [16] subject. In our understanding, these issues need to be worked out and doctors need to be trained to deal with the terminality of life.

Another factor to be considered is legal uncertainty, due to the lack of specific legislation cited pre- 
viously, which can also lead to endless treatments and sufferings [17] that are not listed as accepted on the patient's VT.

These two associated conditions appear, according to Saioron I, Ramos FRS, Amadigi FR, Diaz OS (2017), presenting the culture of curative practice in academic formation as another factor and the view of death as a failure [18] in professional practice.

It is considered an urgent and broad need for modification in medical training. The prognostic information is the duty of the physician, according to the Code of Medical Ethics in article 34, and the difficulty of dealing with finitude becomes harmful to all involved, patients, doctors and family. There is a recent report on the "Communication of bad news" with the Spikes protocol, but it is still new considering the results found [19].

The Spikes protocol [20] represents an important aid to the professional, who is obliged to communicate to the patient its diagnosis and prognosis. Several emotions may come to light at this time, and the professional may fear accusations of being guilty, fear of therapeutic failure, feelings of impotence and personal fear of illness and death [21]. This could lead the doctor to use defense mechanisms that will be harmful to the patient and to himself.

Training communication skills becomes essential, since the professional will need to be prepared, even for the next step, with its patient, discovering how much the patient already knows about its illness and the expectations, giving comprehensible information according to its desire of knowing whether or not to give emotional support and, if possible, engages the patient in a treatment strategy, knowing information is a means and not an end and that it must primarily care about nonmaleficence, or beneficence. A task of great importance and that demands deep sensitivity of the professional. In this case, greater depth is needed to better prepare the physician in its training, guidingit in the procedure and in the perception of the ideal moment for the most appropriate performance in these situations.

The ADW are also cited, not only in a context of reflections, but also in the analysis of contradictions, because although there have been informative guides about them, in Spain the theme remains unknown [22].

There is a suggestion of permanent communication between the doctor and its patient but, according to Martinez, this may not happen, using the professional of the ADW to feel unconcerned about the patient and that there is still the possibility of different values of autonomy in different ethnic groups, a situation that would bring another variable to be considered.

In addition to these possible contradictions, he further states that "the greatest danger of health care in the twenty-first century is not the physician's autocratic paternalism but the respectful abandonment of the sick" [22].

In relation to the approach of people with compromised decision competence, according to the author, on the second article cited [4], when returning to the research, the minor did not have a chronic disease, or any degenerative disease and the type of abuse was related to their physical and emotional integrity.

The concern of a child being conceived, for the purpose of being a donor to an older brother who is a holder of a disease like leukemia or another, came to generate so much controversy that a film with issues related to this theme was produced (My sister's keeper). It was discussed how much one can submit to the suffering, to relieve the suffering of the other, in addition, it was discussed the complex situation in which the parents give their consent, being with its condition of impartiality compromised [23].

There are few articles that address the risks and adverse events of donation of blood and bone marrow and peripheral blood stem cells, but they do exist. They may be linked to anesthesia, the duration of it, allergic reactions, cardiovascular events such 
as tachycardia, bradycardia, hypotension, vomiting, blood transfusion issues, pain, mechanical injury, lumbar stiffness, anemia, need for iron supplementation, infections, complications with reports of a case of pneumothorax with hydrothorax after central venous catheterization [24].

In fact, Bioethics treats and clarifies this question, in the following way: "Every human being, by the circumstance of being an integral part of our biological species, has its own dignity that prevents its use for any purpose other than the promotion of its personal fulfillment." [25].

As for Brazilian legislation, it has changed in relation to people with disabilities. The Brazilian Law on the Inclusion of People with Disabilities or Statute of People with Disabilities no 13.146 of July 6, 2015 brought important changes and undoubtedly had as its objective to promote respect for the inherent dignity of each human being, but if on the one hand it values the citizen, it neglects to protect its employees, especially those of greater vulnerability [26].

The child up to the age of 16 , by absolute incapacity, exercises its rights and duties by representation. The curatorship is related to patrimonial and business rights.

In the case of the ADW, "they are manifestations very distant from those related to patrimonial legal transactions, since they concern what is genuinely human: dignity in living, in surviving and dying" [27]. Here, reflections are meant for adults with compromised decision competence.

If this person has compromised decision competence and acts according to this compromised understanding, if it gives an informed consent for some participation in pharmacological research or even organ donation, what kind of bioethics is implemented into this? Since Law 13,146 / 2015 "provides that the custodian will only affect the acts related to patrimonial and negotiating rights and that their definition does not reach the right to the body..." [27], the situations in which the guardianship would be extended to existential conditions would be considered as an extreme and exceptional measure, having, in our view, a gapto be actively filled by the search for legal protection to observe the principle of beneficence.

"To offer private autonomy to those who can't exercise it with meaning is not to pay tribute to their freedom, but rather leave their legitimate interests at the mercy of the holders of opposing interests." [28]

As for the child, who has in its parents, its legal representatives, in which instance does the appeal occur in the case of donations, such as those referred to in the above text? [4, 23, 24].

Regarding the Resolution and the order of the FCM, it is necessary to discuss in a practical way its applicability, being the resolution itself well-reasoned in its argumentation.

\section{Conclusion}

This work reinforces the need for inclusion and maintenance of the discipline of Bioethics in the training of health professionals, as a way to protect and give patients access to their rights, and professionals the perception of the need to share with the patients, whenever possible, the decisions of their procedures, in the care of the diseases they encounter, in addition to the dissemination and updating of studies and advances in Bioethics, whenever possible, for those who have already completed their graduations.

This research also suggests that the diagnosis of the disease that could compromise the decisionmaking competence of the patient in the future is followed by actions that stimulate the elaboration of Advance Directives of Will and that criteria for the evaluation of partial competence are developed.

It is suggested an integrated effort of the institutions related to health and Bioethics, in order to create a mechanism in Brazil, similar to the one created in Portugal, the National Registry of Vital 
Testament [25], avoiding situations such as that referred to in the FCMOrder No. 526 / 2016 [6], in which the patient, diagnosed as having Alzheimer's, attempted to register its advance directives without success.

It is also important to develop new mechanisms in the health system so that the child can be protected in its dignity and in its right to an open future, being in a condition of great vulnerability.

\section{Acknowledgments}

Miranda TA: Hematologist and Hemotherapist, technical officer of the transfusion agency of the Hospital Carlos Chagas, Rio de Janeiro, RJ, Brazil.

Moraes TM: Psychiatrist, PhD in Psychiatry, Universidade Federal do Estado do Rio de Janeiro, Rio de Janeiro, RJ, Brazil.

Associate Professor, Universidade Federal do Estado do Rio de Janeiro, Rio de Janeiro, RJ, Brazil.

\section{References}

1. Conselho Federal de Medicina. Resolução CFM No. 1931, de 17 de setembro de 2009. Aprova o Código de Ética Médica. (Publicada no Diário Oficial da União. Brasília, No. 183, p.9024 September, 2009. Seção 1). Available at: https://portal.cfm. org.br/images/stories/biblioteca/codigo\%20de\%20etica $\% 20$ medica.pdf. Accessed April 2, 2019.

2. Beauchamp T, Childress J. Principles of biomedical ethics. 6th edn. New York: Oxford University Press; 2008.

3. Bravo G, Rodrigues C, Thériaul V, Arcaud M, Downie J, Dubois $M$ et al. Should Medical Assistance in Dying Be Extended to Incompetent Patients With Dementia? Research Protocol of a Survey Among Four Groups of Stakeholders From Quebec, Canada. JMIR Res Protoc. 2017; 6(11): e2o8, doi: 10.2196/ resprot.8118.

4. Chan TK, Tipoe GL. The policy statement of the American academy of pediatrics- children as hematopoietic stem cell donors- a proposal of modifications for application in the UK. BMC Med Ethics. 2013; 14:43, doi 10.1186/1472-6939-14-43

5. Conselho Federal de Medicina. Resolução CFM No. 1.995, de 31 de agosto de 2012. Dispõe sobre as diretivas antecipadas da vontade dos pacientes. Available at: http://www.portalmedico. org.br/resoluções/CFM/2012/1995_2012.pdf. Accessed March 3, 2018.
6. Conselho Federal de Medicina. Despacho CFM No. 526/2016. Aprovado em reunião de diretoria em 25/10/2016. Expediente CFM n6688/2016. Assunto: Diretivas antecipadas da vontade e dúvida do cartório de registro. Available at: http://www. portalmedico.org.br. Acessed March 3, 2018.

7. World Medical Association - Declaration of Helsinki. Princípios éticos para pesquisa envolvendo seres humanos. Available at: $\quad$ https://www.wma.net/policies-post/wma-declarationof-helsinki-ethical-principles-for-medical-research-involvinghuman-subjects/. Accessed April 2, 2019

8. Council of Europe. Convenção para a proteção dos Direitos Humanos e da Dignidade do ser Humano Face à aplicação da Biologia e da MedicinaAvailable at: https://www.coe.int/en/ web/conventions/full-list/-/conventions/treaty/164. Accessed April 2, 2019.

9. Unesco. Declaração Universal de Bioética e Direitos Humanos. Available at: https://unesdoc.unesco.org/ark:/48223/ pf0000146180 por. Accessed April 2, 2019.

10. Dadalto L, Tupinambás U, Greco DB. Diretivas Antecipadas de Vontade: Um Modelo Brasileiro. Rev. bioét. 2013; 21 (3): 463-76.

11. Rodolphi AC, Rangel TLV. O Testamento Vital em Pauta: a Autonomia da Vontade à Luz dos Princípios Norteadores da Bioética. Revista Âmbito Jurídico 2017; XX, n.164.

12. Bomtempo TV. Early Directives of Will: An Instrument That Ensures the Will to Die Dignely. Journal of Bioethics and Law 2012; on one. 26: p. 22-30.

13. Alves CA, Fernandes MS, Goldim JR. Diretivas Antecipadas de Vontade: Um Novo Desafio Para a Relação Médico Paciente. Rev. HCPA 2012; 32 (3): 358-362.

14. Fernandes L. Aspectos Éticos e Legais nos Estágios Avançados de Demência. Acta Med Port 2008; 21(1): 65-72.

15. Nunes MI, Anjos MF. Diretivas Antecipadas de Vontade: Benefícios, Obstáculos e Limites. Rev. bioét. (Impr.). 2014; 22 (2): 241-251, http://dx.doi.org/10.1590/1983-80422014222005.

16. Gomes BMM, Salomão LA, Simões AC, Rebouças $B O$, Dadalto L, Barbosa MT. Diretivas Antecipadas de Vontade em Geriatria. Rev. bioét (Impr.). 2018; 26 (3): 429-39, http://dx.doi. org/10.1590/1983-80422018263263

17. Scottini MA, Siqueira JE, Moritz RD. Direito dos Pacientes às Diretivas Antecipadas de Vontade. Rev. bioét. (Impr.). 2018; 26 (3): 440-50, http://dx.doi.org/10.1590/1983-80422018263264

18. Saioron I, Ramos FRS, Amadigi FR, Diaz PS. Diretivas Antecipadas de Vontade: desafios legais e educacionais na visão de enfermeiros. Rev. Eletr. Enf. 2017; 19:a44. Available at: http:// dx.doi.org/10.5216/ree.v19.43587. Accessed March 2, 2019.

19. Comin LT, Panka M, Beltrame V, Steffani JA, Bonamigo EL. Percepção de pacientes oncológicos sobre a terminalidade de vida. Rev. bioét. (Impr.) 2017; 25(2): 392-401. Available at: http:// dx.doi.org/10.1590/1983-80422017252199. Accessed March 3, 2019. 
20. Baile WF, Buckman R, Lenzi R, Glober G, Beale EA, Kudelka AP. SPIKES-A Six-Step Protocol for Delivering Bad News: Application to the Patient with Cancer. The Oncologist 2000; vol. 5; no. 4: 302-311. Available at: doi: 10.1634/theoncologist.5-4-302. Accessed March 10, 2019.

21. Carqueja E, Comunicação. In: Nunes R, Rego F, Rego G. Enciclopédia Luso-brasileira de Cuidados Paliativos. Coimbra. Ed. Almedina; 2018. P. 73-81.

22. Martinez K. The documents of anticipated will. Anales Sis San Navarra2007; 30(Suppl 3): 87-102vol. Available at: http:// scielo.isciii.es/scielo. php? script=sci arttext\&pid=\$113766272007000600007\&lng=es. Accessed March 15, 2019.

23. Giansante ALV, Nojiri S. Como o filme uma prova de amor lida com a questão do "irmão salvador" (e o que podemos aprender com ele). Revista de Direito, Arte e Literatura 2016; v. 2; e-ISSN: 2525-9911: p.17-32, doi: 10.21902/. Available at: https://www. researchgate.net/publication/322595677 Como o Filme Uma Prova de Amor Lida Com a Questao do Irmao Salvador E o que Podemos Aprender Com Ele. Accessed March 15, 2019.

24. Styczynski J, Balduzzi A, Gil L, Labopin M, Hamladji RM, Marktel $S$, Yesilipek MA et all. Risk of complications during hematopoietic stem cell collection in pediatric sibling donors: a prospective European Group for Blood and Marrow Transplantation Pediatric Diseases Working Party study. BLOOD 2012; 119; Issue 12: 2935-2942, doi 10.1182/blood-2011-04-349688.

25. Nunes R. Diretivas antecipadas de vontade. Brasília, Conselho Federal de Medicina/Faculdade de Medicina da Universidade do Porto, 2016.

26. Cabral LCL. Pessoas com deficiências: A capacidade é a regra!. Saber Digital 2016; v.9; n.1: p. 79-92. Available at: https:// docplayer.com.br/69204610-Pessoas-com-deficiencias-acapacidade-e-a-regra.html. Accessed April 1, 2019.

27. Meirelles JML, Diretivas antecipadas de vontade por pessoa com deficiência. In: Menezes JB, Direito das pessoas com deficiência psíquica e intelectual nas relações privadas, 1 ed, Rio de Janeiro, Editora Processo, 2016, v.1, p. 713-731.

28. Ribeiro J S. O problema do contrato: as cláusulas contratuais e o princípio da liberdade contratual. Coimbra: Almedina; 1999.
Publish in International Archives of Medicine

International Archives of Medicine is an open access journal publishing articles encompassing all aspects of medical science and clinical practice. IAM is considered a megajournal with independent sections on all areas of medicine. IAM is a really international journal with authors and board members from all around the world. The journal is widely indexed and classified Q2 in category Medicine. 